\title{
The Effectiveness of the Ministry of Social Family's Hope Program (Program Keluarga Harapan) in Increasing the Welfare of the District of Medan Johor
}

\author{
Heriana Bangun; Matias Siagian; Humaizi \\ Faculty of Social and Political Sciences, University of Sumatera Utara, Indonesia \\ http://dx.doi.org/10.18415/ijmmu.v6i4.956
}

\begin{abstract}
The Ministry of Social Family's Hope Program (Program Keluarga Harapan) is a conditional cash transfer program for poor families or known internationally as Conditional Cash Transfers (CCT). Social Family's Hope Program (Program Keluarga Harapan) is a social protection program that provides cash assistance to underprivileged households and for members of Keluarga Penerima Manfaat (KPM) Beneficiary Families who have health components (toddlers and pregnant women), education (elementary, junior high, and high school children), and welfare social (elderly and social disability).

This program, in the short term aims to reduce the burden of underprivileged households and in the long run it is expected to break the intergenerational poverty chain, so that the next generation can get out of the poverty trap. The effectiveness of the Ministry of Social Family Hope Program is measured by several indicators, namely the accuracy of the targets, the implementation of program socialization, the achievement of program objectives, and program evaluation.

This research was conducted in Medan Johor District. The methods in this research is descriptive research with quantitative research methods. Quantitative descriptive research uses words, images, and not entirely numbers when data is collected. The population in this research was 2,589 and using the multi-stage sampling method, through the proportionate stratified and simple random sampling stages a sample of 259 members of beneficiary families was taken.

The results of the research indicate that in general, the implementation of the Ministry of Social Affairs' Family Hope Program in Medan Johor District has been running effectively. However, there are still some aspects that have not fully met the effectiveness of this program, such as officers (assistants) who have not performed their duties properly, Beneficiary Families who often do not attend group meetings, and issues such as zero balance, damaged or lost cards that there is no substitute yet, and the Beneficiary Families 's behavior and point of view regarding assistance from the Government are not yet correct.
\end{abstract}

Keywords: Effectiveness; Family Hope Program; Medan Johor 


\section{Introduction}

Poverty is a condition of a person or group of people unable to fulfill their basic rights to maintain and develop a dignified life. This concept is quite broad in scope or multidimensional so it is often less measurable. The concept of poverty that is applied in many countries including Indonesia is the ability to meet basic needs. Poverty is marked by the low quality of life of the population, education, health, and nutrition. The burden of poverty is strongly felt by certain groups such as women and children which results in the threat of their future (Suharyanto, in Syawie, 2011). Poor families have low purchasing power, are also unable to provide proper education for children. Most of the children of very poor families do not go to school because they have to make a living (Konig, 2011). The inability to pay especially for transportation to school and the low capability of causing children to discontinue education causes the quality of future generations and poor families to always be low and eventually trapped in a cycle of poverty (Bappeda, 2009).

Poverty can affect family life in a number of other things. From the perspective of the poor, Kempson (1996) shows that poverty impacts four broad areas, namely (1) psychological, where poverty is associated with loss of self-esteem, feelings of helplessness, anger, anxiety, and feelings of boredom that are very strong; (2) physical, i.e. poverty is considered to damage health and well-being; (3) relational, i.e. poverty makes social and personal relationships worse and the stigma associated with poverty really colors the relationship; and (4) practical, where poverty limits choices, spending and childcare. That is, poverty almost damages all areas of life, especially if poverty is classified as chronic. The risk of children from chronic poor families living in poverty as adults are $35 \%$ higher than children who are not from chronic poor families (Pakpahan, Suryadharma, and Suryadi, 2009).

The problem of poverty is inseparable from the national strategy aimed at realizing social and economic welfare for the people of the country as a whole. In addition to the national strategy, the state in its efforts to reduce poverty also refers to international policy. Millennium Development Goals (MDGs) is an international policy that addresses poverty reduction, in which there are programs that are actually related to a country's national strategy. As a country that has signed the MDG declaration, Indonesia must have a commitment to implement programs related to Indonesia's national strategy itself. The problem of the still large number of poor people in Indonesia is caused by several things, among others, First, equitable distribution of development has not been spread evenly. The high unemployment rate causes a lack of income for the poor. Second, the poor have not been able to reach basic services and facilities such as education, health, drinking water and sanitation, and transportation. Malnutrition still occurs in the poorer segments of society. This is mainly due to the inadequate coverage of social protection for the poor. But since 2015, the MDGs have been replaced by SDGs.

2015 was a transition year from the Millennium Development Goals (MDGs), 2000-2015 to the 2016-2030 sustainable development goals (SDGs). Recalling, the MDGs consist of eight goals, namely alleviating extreme poverty and hunger, achieving universal basic education, promoting gender equality and empowering women, reducing infant mortality, improving maternal health, and fighting HIV / AIDs, malaria and diseases others, guaranteeing environmental sustainability, and developing a global partnership for development. While the SDGs consist of 17 goals with 169 targets. These 17 goals will be officially declared at the UN General Assembly on 25-27 September 2015. After going through a long negotiation process since 2012, then on 12 August 2015 the UN member states finally agreed with the 17th goal formulation the.

Ending all forms of poverty wherever placed as the first goal, following the second goal of eradicating hunger, striving to ensure food availability, improving nutrition and promoting sustainable agriculture. The United Nations places a healthy goal and promotes the welfare of all people at all age levels as a third goal. Whereas ensuring quality inclusive and equal education and promoting lifelong learning opportunities for all people are placed as the fourth goal. The UN also recognizes that the issue of gender equality must receive attention in the SDGs, and therefore, in the fifth objective the need for

The Effectiveness of the Ministry of Social Family's Hope Program (Program Keluarga Harapan) in Increasing the Welfare of the District of Medan 
achieving gender equality and empowering all women and girls is formulated. No less important is the sixth goal, which is to guarantee the availability and sustainable management of water and sanitation for all. Following the guarantee of everyone's access to affordable, reliable, sustainable and modern energy is the seventh goal. Whereas the eighth objective relates to efforts to promote inclusive and sustainable economic growth and the provision of full and productive employment and decent work for all people.

Infrastructure development that spurs development, promotes inclusive and sustainable industrialization and utilizes innovation becomes the ninth goal, followed by a determination to reduce inequalities within and between countries as the tenth goal. While the eleventh goal is to create cities and settlements that are inclusive, safe, support progress and sustainable. Ensuring sustainable patterns of consumption and production are formulated as the twelfth goal; while taking urgent action to storm the climate change and its various impacts including the thirteenth goal. Safeguarding and utilizing the oceans, seas and their resources for sustainable development is placed as the fourteenth destination. Whereas the fifteenth goal is to protect, restore and advance the use of earth's ecosystems, manage forests in a sustainable manner, demolish desertification, stop and restore degraded land, and stop the loss of biodiversity. The last two goals speak of the promotion of a peaceful and inclusive community life for sustainable development, providing access to justice for all people and building effective, accountable, and inclusive institutions at all levels (goal 16); and the seventeenth goal emphasizes the need to "strengthen ways of elaborating and revitalizing partnerships for sustainable development (Indonesian Ministry of Social Affairs Research and Development, 2015).

The 2008 PKH General Handbook states that the poverty level of household is generally related to the level of education and health. The low income of a very poor family causes the family to be unable to meet their educational and health needs, even to a minimum. Mother's health care for pregnant women in very poor families is often inadequate, leading to the poor health of babies born or even infant deaths. The infant mortality rate in the lowest income group in 2003 was 61 percent. The maternal mortality rate in Indonesia is also high, around 310 women per 100,000 live births, or the highest in Southeast Asia. The high maternal mortality rate is caused by the absence of medical personnel at birth, health facilities that are not available when needed action, or many poor households who prefer traditional health workers than other medical workers. The low health condition of very poor families has an impact on the suboptimal process of growth and development of children, especially at 0-5 years of age. In 2003, the under-five mortality rate in the lowest-income population group was 77 percent per 1000 live births. In 2002-2005, there was a tendency for an increase in cases of malnutrition which increased from 24.5 percent in 2000 to 29 percent in 2005 .

Poor nutrition has a negative impact on productivity and endurance of a person so that it causes trapped in a cycle of poor health. Often not going to school because of illness can cause children to drop out of school or at least underachieve in school. There are also some of the children of very poor families who have never attended school because they have to help make a living. Although primary school enrollment rates are high, there are still many children of poor families who drop out of school or do not continue to SMP / MTs. There are still many poor families who cannot meet the basic needs of education and health due to the root of the problem that occurs both on the demand side and the service side (supply). On the demand side, the biggest reason for not continuing school is because there is no cost, working to make a living, and other reasons. Likewise for health, poor families cannot afford maintenance or health care for their family members due to low income levels. Meanwhile, on the supply side which causes low access to education and health among others is the unavailability of health and education services that are affordable to poor households. The cost of services that are unaffordable for poor households and the relative distance between residence and location of services is a major challenge for education and health service providers. By taking into account the conditions as above, the government issued a policy program which is the development of a social protection system that can alleviate and help very poor households in terms of accessing health services and basic education in the hope that this program will be able to reduce poverty in our country. Thus, in the context of accelerating poverty 
reduction and developing a social security system, the government launched the Family of Hope Program (PKH).

This program is motivated by the main development problems namely the large number of poor people and the low quality of human resources. PKH is a social assistance to Very Poor Households (RTSM) that meet certain qualifications (chronic RTM, prone to shocks) by imposing certain conditions that can change the behavior of individuals and communities. PKH as social protection is an effort to raise the level of welfare of the people who don't have the power, so it needs strengthening or empowerment so that the residents have the power to get out of their poverty circle. (www.sinarmedia-ws.com/index.php accessed on 09-20-2010). The Family of Hope Program began to be implemented in North Sumatra Province in 2008 which covered three Regencies / Cities namely Medan, Nias and Central Tapanuli as a pilot area with a total of 33 districts. North Sumatra was made one of the target areas of the Family Hope Program considering that poverty conditions in this area are still quite high, according to data from the Central Statistics Agency (BPS) of North 2009 as of June 2009 there were around $11.5 \%$ or equivalent to 1.5 million people out of a total of 13,248 million souls of the population in the poverty line. This poverty condition causes many poor families who cannot access education and health properly. (http // www.pkh.depsos.go.id, accessed on May 28, 2018, at 4:14 p.m).

There are 21 Districts that have implemented the Family Hope Program in Medan City, one of which is Medan Johor District. It is hoped that with the assistance from the Family Hope Program, it will reduce the burden on very poor households who are PKH recipients in Medan Johor District in accessing these basic services. In the implementation of the Family Hope Program, there are certainly many things to deal with, and based on the above explanation, the writer feels interested to see the effectiveness of the implementation of PKH directly in the field, which includes the stages, problems and outcomes and benefits that can be felt by the poor. There are 4 things that are seen to determine whether the Family of Hope Program has been implemented properly, namely: the accuracy of the program objectives, program socialization, program objectives, and program monitoring.

\section{Research Method}

Through quantitative descriptive research, the author wants to make a comprehensive picture of the Effectiveness of the Family Hope Program (PKH) of the Ministry of Social Affairs in Improving Social Welfare of Medan Johor District. In a simple population can be interpreted as a collection of objects, objects, events or individuals that will be studied in a study (Siagian, 2011: 53). The population in this research were all participants of the Ministry of Social Family Hope Program (PKH) in Medan Johor District in 2018, totaling 2,586 Beneficiary Families. In this research the authors used the Multi Stage Sampling method in the sampling process because it saw a large number of population and also homogeneous. To determine sample size, Gay in Sevilla et al (1993: 163) mention that for descriptive research - a minimum sample of 10 percent of the population. Based on this opinion the authors determined the number of samples in the research were 259 samples that could represent KPM Beneficiaries of the Family Hope Program (PKH) Ministry of Social Affairs. The determination of this sample is done by proportioned stratified random sampling.

\section{Analysis of Characteristics of Respondents}

\section{a. Distribution of Respondents by Age}

Classification of respondents by age level, which is dominated by the number of respondents aged between 41-50 years as many as 163 respondents or around 63 percent of the total respondents, respondents aged between 31-40 years as many as 57 respondents or about 22 percent of the total 
respondents. Then aged 51-60 + years as many as 30 respondents or about 11.5 percent and for the age level between 21-30 as many as 9 respondents or only about 9 percent of the total number of respondents.

\section{a. Distribution of Respondents Based on Religion}

Respondents who embraced Islam totaled 226 respondents (87\%) and respondents who embraced Protestant Religion were 29 respondents $(11 \%)$ while those who embraced Catholic Religion were 4 respondents (2\%). This religious distribution is a picture of the people in Medan Johor Subdistrict that receive Social Assistance Program (PKH) assistance from the Ministry of Social Affairs, which is dominated by people who embrace Islam, only a small portion of the community embraces Protestant Religion and Catholicism.

\section{b. Distribution of Respondents Based on Education}

As many as 154 respondents (67\%) who had reached junior high school, there were 52 respondents $(20 \%)$ who sat until elementary school, 26 respondents $(10.3 \%)$ who graduated from high school, and 4 respondents (1.55\%) never been in school. It can be concluded that the level of education is still low due to the non-existent costs for schools and continuing education to a higher level, so that the average income of the population in Medan Johor District tends to be relatively low. The low level of education of the population also affects their children, where the motivation of parents to send their children to the highest level is also low.

\section{c. Distribution of Respondents by Job}

From the data, it is likely that KPM who live in Medan Johor sub-district are working as household members, which includes washer washers, scourers, cooks, cleaners of other people's houses, etc. 171 respondents $(66 \%)$ of the total respondent. There are 48 respondents $(18.5 \%)$ who are housewives. There are 36 respondents $(13.9 \%)$ who work as traders, both street vendors, retail traders, and mobile traders. 2 respondents $(0.8 \%)$ work as factory workers and there are 2 respondents $(0.8 \%)$ who work as builders.

\section{d. Effectiveness of the Family Hope Program (PKH) Ministry of Social Affairs}

The effectiveness of the Ministry of Social Family Hope Program (PKH) is measured by several indicators namely targeting accuracy, implementing program socialization, achieving program objectives, and evaluating programs.

\section{a. Target accuracy}

As many as 47 respondents who have been PKH participants since 2008. The Ministry of Social Family Hope Program (PKH) has been around since 2007 in Indonesia, and in 2008 was the first time the PKH Ministry of Social Affairs entered North Sumatra. From 2008 to 2015 there were no additional participants / PKM PKH Ministry of Social Affairs, then there were additional participants in 2015, but for the Deli Serdang area only. Until finally there was an increase in participants / KPM in 2016 for the Medanm City region as well as there was an increase in companions to take care of the new KPM. There were 77 respondents (\%) who were KPM in 2016. Furthermore, in 2017 there was an increase in PKH participants / KPM again, but for Medan Johor District only in Pangkalan Mashyur Sub-District. There were 41 respondents (\%) who became KPM PKH Ministry of Social Affairs in 2017. And finally, there was an increase in Medan Johor District to meet 10 million PKH participants in order to reduce poverty as

The Effectiveness of the Ministry of Social Family's Hope Program (Program Keluarga Harapan) in Increasing the Welfare of the District of Medan 
proposed by President Jokowi. There were 94 respondents (\%) who participated / PKPM PKM Ministry of Social Affairs who came from 6 villages in Medan Johor District.

\section{b. Implementation of the Socialization Program}

A total of 128 respondents (49.4\%) participated in the PKH Ministry of Social Affairs because they were initially found from neighbors. There were 79 respondents $(30.5 \%)$ received information from family members who had participated in PKH in the previous year, for example his sister, brother, brother-in-law, son-in-law, etc. and said that his name was listed in the PKH validation data of the Ministry of Social Affairs. There were 49 respondents (18.9\%) who were directly found by their assistants because neighbors and officers in the District did not know their whereabouts and also did not know them. And there were 3 respondents $(1.15 \%)$ who were contacted by headman that the PKH Ministry of Social officials were looking for their addresses to become PKH Social Ministry candidates.

\section{c. Achieving Program Objectives}

As many as 259 respondents (100\%) chose the answers since there had been a lot of Government assistance to the community but through the District officials or officials, so that the aid provided was free of charge, only once and then stopped so that the money received was also out of control and made the function of the community is not organized, so is often the case of misuse of the distributing officer.

\section{d. Monitoring Program}

There were 187 respondents (100\%) who chose "PKH aid money every month" because PKH aid money was distributed 4 times a year ie in January, April, July and October and not every month. There are 72 respondents $(27.8 \%$ ) who choose BPNT (rice and eggs) every month because they are PKH participants in 2018 and BPNT balances have never entered into their own KKS.

\section{Conclusion}

To improve the welfare of the community, the influence of the program is very important to know done in order to achieve the stated goals. The effect of the program in an effort to improve the welfare of the community can be formulated as the level of realization of the target which shows how far the target has been achieved.

From the analysis of the data obtained, conclusions can be made as follows:

1. The influence of the Family Hope Program (PKH) on the socio-economic community has been felt by PKH participants. School fees and toddler health costs that have been a problem of Very Poor Households have been helped by the funding of the Family Hope Program (PKH). With the Family Hope Program (PKH), PKH participants can save because of school fees and the health of pregnant women and toddlers have been alleviated by the Family Hope Program (PKH). By saving, PKH participants can plan their life needs in the future and can have savings for unexpected things. 
2. The Family of Hope Program (PKH) is right on target aimed at poor families. This was realized because of the good performance and good roles of the facilitators, without good performance and role, it was certain that PKH aimed at poor families was not on target.

3. PKH participants are very happy with $\mathrm{PKH}$ and their activities provide positive things, especially for the field of education, can realize an increase in school-age education, reduce the level of school drop-out children, has been carried out as expected although not yet achieving maximum results.

The obstacles or obstacles faced in the implementation of PKH in Medan Johor Sub-district are the participation of PKH participants is still lacking. PKH participants are busy working outside the home, and the notion that group meetings are a waste of time. In fact the group meeting activity is a means of gathering information about the development of PKH.

\section{Suggestion}

As for suggestions to have a positive influence on the Family Hope Program (PKH) hereinafter:

1. The Family of Hope Program (PKH) is a cross-sectoral program so that in carrying out $\mathrm{PKH}$ activities, parties involved in PKH implementation such as PKH assistants, PKH participants / beneficiaries, education and health officials, District UPPKH, and District UPPKH / The city developed a good cooperative relationship.

2. To achieve the desired goals in the Family Hope Program (PKH) in the fields of education and health, namely improving the educational status of school-age children, reducing the level of child labor, street children, dropping out of school, and maintaining the health of the mother's fetus and toddlers' health, hard work is needed companion of the Harapan Families Program in the District. It is necessary to carry out socialization, motivation, and knowledge as well as information without being bored about the importance of education and health, so that awareness and behavior change from PKH participants / beneficiaries is built.

\section{References}

\section{Alfiandri, Aminah dkk. Efektivitas Program Kartu Bintan Sejahtera (KBS) dalam Bidang Pendidikan dan Kesehatan di Kabupaten Bintan. Jurnal Ilmu Administrasi Negara FISIP UMRAH. (http://jurnal.umrah.ac.id/?p=3891)}

Amirullah dan Rindyah Hanafi. 2002. Pengantar Manajemen. Yogyakarta: Graha Ilmu.

Arikunto, Suharsimi. 2010. Prosedur Penelitian Suatu Pendekatan Praktik. Jakarta: Rineka Cipta

The Effectiveness of the Ministry of Social Family's Hope Program (Program Keluarga Harapan) in Increasing the Welfare of the District of Medan 
2002. Manajemen Penelitian. PT Asdi Mahasatya: Jakarta.

Bappenas. 2009. Laporan akhir Program Perlindungan Sosial Program Keluarga Harapan: Deteksi dini dampak Program Keluarga Harapan (PKH) terhadap kesehatan dan pendidikan. Bappenas, Direktorat Perlindungan dan Kesejahteraan Masyarakat.

Buku pedoman Umum PKH

Campbell, J.P 1989, Teori Efektivitas, dalam Richard M:Efektivitas Organisasi 2005 Bandung: Erlangga

Data SP2D/ BNBA PKH Kota Medan Tahun 2018

Departemen Pendidikan Nasional.2008. Kamus Besar Bahasa Indonesia. Jakarta: Balai Pustaka.

Prabowo. 2009. Efektivitas Program CSR Yayasan Unilever Indonesia (studi kasus : Pasar Minggu

Jakarta). Jurnal pada Institut Pertanian Bogor.

(https://repository.ipb.ac.id/handle/123456789/11420)

Ellis, G.F.R. 1984. The Dimension of Poverty. Chicago: The Dryden Press.

Fatmah. 2010. Gizi Usia Lanjut. Erlangga : Jakarta.

Frida. 2011. Efektivitas Pelaksanaan Program Raskin di Kelurahan VI Suku Kecamatan Lubuk Sikarah Kota Solok. Jurnal Universitas Andalas.(http. repository.unand.ac.id/17295/)

Gibson, et al, Organisasi dan Manajemen; Perilaku, Struktur, Proses, 1990, Jakarta: Erlangga.

Hasbi Iqbal. 2008. tesis dengan judul Implementasi Kebijakan Program Keluarga Harapan di Kabupaten Kudus. Jurnal (https://ejournal3.undip.ac.id/index.php/jpgs/article/.../18125)

Husein Umar, 1998, Metode Penelitian, Jakarta, Raja Grafindo Persada.

Inpres nomor 3 Tahun 2010

Inpres nomor 1 Tahun 2013

Kasiram. 2010. Metodologi Penelitian Kualitatif dan Kuantitatif. Malang: UIN.

Kempson, E. 1996. Life on a low income. York: Joseph Rowntree Foundation.

Konig, S. 1995. The cost of malnutrition. Techinal Support Group F. Hoffman-La Roche Ltd. 4/0895 (2nd ed). No. 50623. Switzerland.

Litbang Kemensos RI, 2015

Rihadini, Mustika. 2012. Efektivitas Pelaksanaan Program Nasional Pemberdayaan Masyarakat Mandiri Pedesaan Pada Kelompok Simpan Pinjam Perempuan (PNPM MP SPP) di Kecamatan Ranomeeto Kabupaten Konawe Selatan Provinsi Sulawesi Tenggara pada periode 2010. Jurnal Universitas Hasanuddin.(http://repository.unhas.ac.id/handle/123456789/1672).

Pakpahan, Y. M., Suryadarma, D., \& Suryahadi, A. 2009. Destined for destitution: Intergenerational poverty persistence in Indonesia. Jakarta: SMERU Research Institute (SMERUWorking Paper, January 2009).

Peraturan Pemerintah Republik Indonesia No.27 tahun 1981. 
Rahmatika. 2011. Analisis Efektivitas Program Pinjaman Dana Bergulir pada Unit Pengelola Kegiatan (UPK) PNPM Mandiri dan Kelompok Simpan Pinjam Perempuan (SPP) di Kecamatan Situjuh Limo Nagari Kecamatan Lima Puluh Kota Tahun 2008-2010.(http://scholar.unand.ac.id/15451/).

Rozi, Akhmad. 2011. Implementasi Program Keluarga Harapan di Kabupaten Tanah Laut. Jurnal Penelitian Kebijakan Pembangunan. Volume 2. (https://msap-unlam.ac.id//AkhmadRozi.pdf).

Sedarmayanti. 2009. Sumber Daya Manusia dan Produktivitas Kerja. Bandung: Mandar Maju.

Septian Dwi Putra. 2013. Efektivitas Program Nasional Pemberdayaan Masyarakat (PNPM) Mandiri Pedesaan dalam Rangka Pemberdayaan Perempuan di Kelurahan Nenang Kecamatan Penajam Kabupaten Penajam Paser Utara. Jurnal Ilmu Pemerintahan Universitas Mulawarman. Volume 1. (http://ejournal.ip.fisip-unmul.ac.id/site/?p=592)

Siagian, Sondang. P. 2006. Sistem Metode Penelitian Kuantitatif Kualitatif dan R\&D. Bandung: CV. Sukendar, Andy. Analisis Efektivitas Penerapan SNI Wajib Ubin Keramik denganMenggunakan AHP.

Subagyo, Ahmad Wito, 2000, Efektivitas Program Penanggulangan Kemiskinan Dalam Pemberdayaan Masyarakat Pedesaan, Yogyakarta : Gadjah Mada.

Sumodiningrat, Gunawan. 2003, Membangun Perekonomian Rakyat, Yogyakarta: Pustaka Pelajar.

Suryabrata, Sumadi. 2008. Metode Penelitian. Jakarta: PT Raja Grafindo Persada.

Syawie, M. (2011). Kemiskinan dan kesenjangan sosial. Informasi: KajianPermasalahan Sosial dan Usaha Kesejahteraan Sosial, 16(3), 213-220.

Wahyu Widodo. 2014. Efektivitas Program Pinjaman Dana Bergulir PNPM Mandiri Perkotaan Dalam Penanggulangan Kemiskinan Kabupaten Sangihe (Suatu studi di Kampung Taloarane Kecamatan Manganitu Kabupaten Sangihe). Jurnal Agro Ekonomi. Volume 35. (http://ejurnal.litbang.pertanian.go.id/index.php/jae/article/view/8614).

Tirtarahardja, Umar \& La Sulo. 2005. Pengantar Pendidikan. PT Rineka Cipta. Jakarta.

Peraturan Pemerintah Republik Indonesia No.27 tahun 1981

Suharto, Edi. 2008. Kebijakan Sosial Sebagai Kebijakan Publik. Bandung: Alfabeta.

Undang-Undang No.2 tahun 1989

Undang-undang nomor 40 Tahun 2004

Undang-undang nomor 13 Tahun 2011

Peraturan Presiden nomor 15 Tahun 2010

Subagyo, Ahmad Wito. 2000. Efektivitas Program Penanggulangan Kemiskinan dalam Pemberdayaan Masyarakat Pedesaan. Yogyakarta : UGM.

Sugiyono. 2016. Metode Penelitian Adminisrasi. Bandung: Alfabeta.

Siagian, Matias. 2011. Metode Penelitian Sosial (Pedoman Praktis Penelitian Bidang Ilmu- Ilmu Sosial dan Kesehatan). Medan: PT. Grasindo Monoratama. 
RinekaCipta. Notoatmodjo. 2010. Metodologi Penelitian Kesehatan. Jakarta : PT. Rineka Cipta.

Website:

(http://digilib.unila.ac.id/12897/118/BAB\%20II.pdf, diakses pada tanggal 13 September 2018)

(http//www.pkh.depsos.go.id, diakses tanggal 28 Mei 2018, pukul 16.14 WIB)

(http://www.academia.edu/2635730/Program_Keluarga_Harapan_di_Indonesia_Dampak_Pa

da Rumah Tangga Sangat Miskin di Tujuh Provinsi, diakses tanggal 02 September 2018)

(http://koleksi.org/teori-efektivitas-menurut-para-ahli, diakses pada tanggal 04 September

2018 pukul 18.30 WIB)

(http://yunitaardha.blogspot.com/2012/04/kumpulan-teori-efektivitas.html,diakses pada tanggal 15 September 2018)

\section{Copyrights}

Copyright for this article is retained by the author(s), with first publication rights granted to the journal. This is an open-access article distributed under the terms and conditions of the Creative Commons Attribution license (http://creativecommons.org/licenses/by/4.0/). 